REFERENCES

Duncan, I. B. R., and Hutchinson, J. G. P. (1961). Lancet, 1, 530

Fulton, F., and Dumbell, K. R. (1949). J. gen. Microbiol., 3, 97. Gardner, P. S. (1961). Brit. med. J., 2, 495

McGregor, C. B., and Dick, K. (1960). Ibid., 1, 91.

Hale, J. H., Lee, L. H., and Gardner, P. S. (1961). Ibid., 2, 728 Kendall, E. J. C., Riddle, R. W., Tuck, H. A., Rodan, K. S., Andrews, B. E., and McDonald, J. C. (1957). Ibid., 2, 131

Kjellén, L., Sterner, G., and Svedmyr, A. (1957a). Acta paediat. (Uppsala), 46, 164.

Zetterberg, B., and Svedmyr, A. (1957b). Ibid., 46, 561.

Knox, E. G., Court, S. D. M., and Gardner, P. S. (1962). Brit. med. J., 2, 692

Munro-Ashman, D., Gardner, P. S., Taylor, C. E. D., and McDonald, J. C. (1958). Lancet, 2, 121.

Ramos-Alvarez, M., and Sabin, A. B. (1958). J. Amer. med. Ass., 167, 147.

Ross, J.' G., and Potter, C. W. (1961). Lancet, 1, 81.

Sommerville, R. G. (1958). Ibid., 2, 1347.

\section{VIRUSES IN LYMPH NODES OF CHILDREN WITH MESENTERIC ADENITIS AND INTUSSUSCEPTION}

BY

THOMAS M. BELL, B.Sc.

Lecturer in Bacteriology

AND

JOHN H. STEYN, M.B., Ch.B., F.R.C.S. Surgical Registrar

From the Departments of Bacteriology and Surgery, University of Aberdeen, and the Royal Aberdeen Hospital for Sick Children

Since the original isolation of members of the adenovirus group from hypertrophied tonsils and adenoids (Rowe et al., 1953), and the discovery that infection with this group may give rise to localized lymphadenopathy (Bell, 1957), several workers have tried to find an association between adenovirus infection and the clinical condition of non-specific mesenteric lymphadenitis (Aird, 1945) ; Kjellén (1955) and Kjellén et al. (1957) reported the isolation of six strains of adenovirus from 113 such cases and Van der Veen (1958) two isolations from an unspecified number of cases.

Ross and Potter (1961) have isolated adenovirus from 11 out of 16 cases of acute idiopathic intussusception. Gardner (1961) examined the faeces from 10 cases of intusssusception and isolated adenovirus from six and herpes simplex virus from one.

In Aberdeen we began to examine lymph nodes removed at operation from cases of non-specific mesenteric adenitis in November, 1959, and included cases of acute idiopathic intussusception from January, 1960. Our aim was to determine whether virus could be isolated from such material and whether the findings differed in any way from those in a control group of children not suffering from these conditions. In a preliminary communication (Steyn and Bell, 1961) we reported the isolation of adenovirus from 10 out of 11 cases of intussusception, from 11 out of 22 cases of mesenteric adenitis, and from 1 out of 23 controls.

This paper deals in more detail with the results of the investigation between November, 1959, and February, 1961.

\section{Methods and Materials}

Three groups of cases were studied: (1) acute idiopathic intussusception, 17 cases; (2) non-specific mesenteric adenitis (identified at operation), 32 cases; and (3) "control" group, 50 cases. The controls were patients submitted to laparotomy for a variety of reasons, the majority being early cases of acute appendicitis subsequently confirmed by histological examination but also including lesions such as intestinal obstruction, swallowed foreign body, and threadworm infestation. Full details are given in Table I.

Table 1.-List of Control Cases

\begin{tabular}{|c|c|c|c|}
\hline Disease & No. of Cases & Diseas $=$ & No. of Cases \\
\hline Appendicitis & . 32 & Spina bifida manifesta & \\
\hline Ingested foreign body & 3 & Crohn's disease & . \\
\hline Blood dyscrasia & .. & Megacolon .. & . \\
\hline Intestinal obstruction & .. & Sonnei dysentery & . \\
\hline Threadworm infestation & .. & Pneumonia $\because$ & . \\
\hline Primary peritonitis .. & . & Abdominal pain & . \\
\hline
\end{tabular}

In each instance a mesenteric gland was removed and clotted blood obtained. A second sample of blood was taken after 10 days. Unfortunately samples of faeces were obtained from only a few of the cases and from none of the controls.

All media used in this investigation were prepared as described elsewhere (Bell, 1962). The monolayer tissue cultures used throughout the investigation were human embryo kidney, human embryo liver, human amnion, and two lines of HeLa cells (Bell et al., 1960 ; Bel, 1962).

For attempted isolation of a virus from the lymph nodes the following procedure was used. After excision the node was placed in tissue-culture-maintenance medium and kept warm (room temperature) until delivered to the virus laboratory. There it was dissected into 1-c.mm. fragments and embedded in a fowl plasma clot as used by Rowe et al. (1953) when they first recovered adenovirus from tonsils and adenoids. The clot was covered with growth medium containing $20 \%$ calf serum and incubated at $34-35^{\circ} \mathrm{C}$. in stationary angled racks. In most cases cells grew out from the fragments in a few days and gave a good cell sheet which sometimes degenerated in a similar way to a cell culture infected with adenovirus. At this stage the tubes were frozen overnight at $-20^{\circ} \mathrm{C}$., thawed out to room temperature, and then alternately frozen to $-70^{\circ} \mathrm{C}$. and thawed to room temperature six times to release any intracellular virus. Cultures which did not grow or which gave non-specific degeneration were treated in the same manner. The resulting fluid from these explant cultures was then inoculated into roller tube cultures of at least three of the cell types in use, and incubated at $37^{\circ} \mathrm{C}$. If degeneration was not seen in two to three weeks the tubes were frozen overnight and passed to fresh cultures. At least three blind passages were made for each specimen before discarding as negative.

Specimens of faeces and appendix were homogenized to give a $10-20 \%$ suspension in tissue-culturemaintenance medium and then treated in the same way as explant tissue fluid.

All viruses isolated were identified by neutralization with specific rabbit antisera, and sera were tested for neutralizing and adenovirus complement-fixing antibody (Bell et al., 1960 ; Bell, 1962). The adenovirus antigen used for complement-fixation tests throughout the study was prepared from suspensions of adenovirus types 1, 3, 4,7 , and 14 grown in human-embryo-kidney cells. 


\section{Results}

From a total of 117 specimens from 99 patients 38 strains of virus were isolated. Isolation from the lymph node was attempted in all but one instance, and the isolation results from these are given in Table II.

TABLE II.-Virus Isolations From the Lymph Nodes

\begin{tabular}{|c|c|c|}
\hline Group & No. Tested & No. Giving Virus \\
\hline $\begin{array}{l}\text { Intussusception } \\
\text { Mesenteric adenitis } \\
\text { Control }\end{array}$ & $\begin{array}{l}17 \\
31 \\
50\end{array}$ & $\begin{array}{r}11 \\
11 \\
5\end{array}$ \\
\hline
\end{tabular}

Of the 38 isolations, 30 were adenovirus and 8 were enteroviruses. These fell into the following serological types: adenovirus types $1,2,3,5$, and 6; Coxsackie group B types 1, 3, and 5; and E.C.H.O. types 9, 11, and Frater. Since this controlled experiment has ended an E.C.H.O. type 7 virus has been isolated from the lymph node of a case of intussusception. Table III shows the distribution of these types among the specimens obtained from each group of cases.

TABLE III.-Virus Types Isolated

\begin{tabular}{l|l|l|l|l|l|l|l|l|l|l|l|l|l}
\hline & \multicolumn{6}{|c|}{ No. of Strains Isolated from Mesenteric } \\
Lymph Nodes
\end{tabular}

* No specimens of faeces obtained from the control group and no virus isolated from the appendix.

In 4 of the 11 cases from which more than one specimen was obtained a virus was isolated from two specimens. In three of these the same adenovirus was isolated from the faeces and the lymph node: adenovirus types 1 and 5 from two cases of intussusception, and adenovirus type 2 from a case of mesenteric adenitis. The fourth case gave an adenovirus type 3 from the lymph node and a Coxsackie B3 from the appendix.

Paired sera, or a single convalescent serum, were obtained from 79 of the 99 cases. These were all tested for adenovirus complement-fixing antibody and neutralizing antibody to the virus type isolated. Sera from cases of intussusception and mesenteric adenitis were also tested for neutralizing antibody to the enteroviruses which were prevalent in the community at the time. The results were divided into three groups: (1) A concurrent infection: indicated by a fourfold or greater rise in antibody. (2) A recent infection : indicated by a high level on antibody in both acute and convalescent specimens or in a single convalescent specimen. Titres

\begin{tabular}{|c|c|c|c|c|}
\hline Group of Cases & No. of Cases & Concurrent & Recent & Doubtful \\
\hline Intussusception & $\begin{array}{l}13 \text { virus }+ \\
4 \text { virus - }\end{array}$ & $\begin{array}{l}5 \\
0\end{array}$ & $\begin{array}{l}3 \\
2\end{array}$ & $\begin{array}{l}5 \\
2\end{array}$ \\
\hline $\begin{array}{l}\text { Mesenteric } \\
\text { adenitis }\end{array}$ & $\begin{array}{l}13 \text { virus + } \\
11 \text { virus - }\end{array}$ & $\begin{array}{l}4 \\
1\end{array}$ & $\begin{array}{l}5 \\
6\end{array}$ & $\begin{array}{l}4 \\
4\end{array}$ \\
\hline Control $\cdot \quad:$ & $\begin{array}{l}2 \text { virus + } \\
36 \text { virus - }\end{array}$ & $\begin{array}{l}0 \\
1\end{array}$ & $\begin{array}{l}0 \\
8\end{array}$ & 27 \\
\hline
\end{tabular}

Virus $+=$ Virus isolated from at least one specimen Virus - $=$ Virus not isolated from any specimen. of $1: 32$ or greater for adenovirus complement-fixing antibody and 320 or greater for enterovirus-neutralizing antibody were taken as significant. (3) Doubtful: which includes those cases where no antibody was found or where the levels were too low to be of any significance. These results are grouped in Table IV.

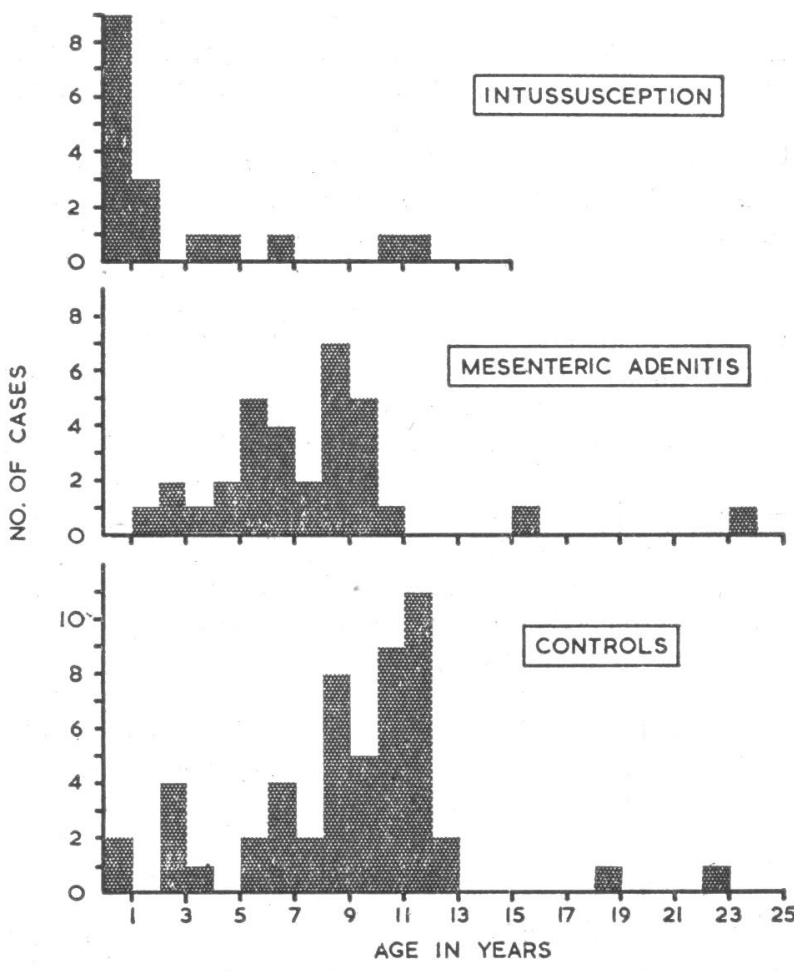

Age distribution of the three groups of cases.

Finally the Chart shows the age distribution of the three groups of cases with relation to isolation of the viruses. All three groups of cases were investigated over the same period and were matched for the actual time of collection.

\section{Discussion}

As can be seen from the Chart, there is variation in the ages of the different groups; in particular among the cases of acute idiopathic intussusception, who are mainly much younger than the others. However, the cases of non-specific mesenteric adenitis and the control cases are reasonably closely matched.

There have been 11 isolations from the lymph nodes of 31 cases of non-specific mesenteric adenitis against 5 isolations from 50 control cases. This difference in the isolation rate is significant at the $5 \%$ level $\left(x^{2}=6.17\right.$. 1 d.f. $0.05>P>0.01$ ). As is to be expected, because of the younger age of the cases of intussusception there has been an even higher proportion of cases in which virus has been isolated. Nevertheless, the higher isolation from the lymph nodes (11 from 17) is thought to be significant.

The types of adenovirus isolated from the lymph nodes show a marked difference between the three groups. All the isolations from the control group are adenovirus type 1, whereas the types isolated from the other two groups are very similar and include types 2, 3, 5 , and 6 as well.

In the preliminary communication (Steyn and Bell, 1961) only the isolation of the adenoviruses was noted. Adenoviruses have been isolated throughout the 16 
months of the investigation, but the greatest number have been found at the times of local prevalence of other clinical adenovirus infections. On the other hand, the enterovirus isolations have occurred only during the periods when enteroviruses have been found in cases of other clinical infections.

These results suggest an association between the presence within the lymph node of the prevalent viruses and the clinical entities of acute idiopathic intussusception and non-specific mesenteric adenitis.

Although only 5 of the 17 cases of intussusception and 5 of the 24 cases of mesenteric adenitis show serologically that a virus infection occurred concurrently with the symptoms, only 1 of 38 controls gave this evidence. However, if the recent infections are added to the concurrent group, 10 of the 17 cases of intussusception and 16 of the 24 cases of mesenteric adenitis indicate infection, against only 9 of the 38 controls. These are significant differences (mesenteric adenitis $\chi^{2}=9.58 . \quad 1$ d.f. $0.01>P>0.001$; intussusception $x^{2}=4.95$. 1 d.f. $\mathrm{P}<0.05$ ).

Thus, although the adenoviruses isolated belong to the same types as those found in hypertrophied tonsils and adenoids, the serological results are very different (Pereira, 1960) inasmuch as in the latter group no difference was observed between the adenovirus complement-fixation titres and those of a control group.

Lymphadenopathy was noticed as one of the most frequent symptoms of adenovirus infection (Bell, 1957), but it is not as common in enterovirus infections, except those due to E.C.H.O. type 11 (Elvin-Lewis and Melnick, 1959). Evidence of lymphadenopathy has been recorded in Scotland during outbreaks of E.C.H.O. type 9 and Frater virus infections (Landsman et al., 1960 ; Bell, 1962). Abdominal pain is well known in enterovirus infections and has been described during outbreaks of respiratory tract infections due to adenovirus types 3 and 7 (Dascomb and Hilleman, 1956; Sobel et al., 1956; Barr et al., 1958), while Williams (1961) recorded that four cases during an epidemic of Bornholm disease in Wales were admitted to hospital with acute abdominal symptoms. It is possible that these abdominal symptoms are those which are clinically dominant in non-specific mesenteric adenitis associated with virus infection.

These viruses can be isolated from the faeces and apparently also from the lymph nodes of normal children (Committee on the E.C.H.O. viruses, 1955; Gardner et al. 1961), but the recovery of the viruses in a significantly higher proportion of cases of non-specific mesenteric adenitis and acute idiopathic intussusception, in combination with the knowledge that these viruses do cause abdominal pain and lymphadenopathy, might suggest a causal relationship rather than a chance association. The possibility of the virus lying dormant for long periods must also be considered, but the serological results, which not infrequently show a definite response, are not wholly consistent with this interpretation.

Before any definite claims can be made it will be necessary to confirm this statistically significant association with very much larger numbers than we have been able to present.

\section{Summary}

Eleven strains of virus were isolated from the lymph nodes of 17 cases of acute idiopathic intussusception,
11 strains from 31 cases of non-specific mesenteric adenitis, and 5 strains from 50 "control" cases. The virus types isolated from the first two series were very similar and comprised adenovirus types 1, 2, 3, 5, and 6 and E.C.H.O. types 7 and 9. The strains isolated from the controls were all adenovirus type 1 apart from one Coxsackie B5. The rate of occurrence of virus in the lymph nodes of cases of mesenteric adenitis was significantly greater than that in the controls, but an accurate comparison between these two groups and the cases of intussusception could not be made owing to the age difference. The serological results showed that the cases of mesenteric adenitis and intussusception had a higher rate of recent infection than the control group.

The results showed a temporal association of the clinical entities non-specific mesenteric adenitis and acute idiopathic intussusception with an infection due to a virus prevalent in the community.

We thank Professor A. Macdonald for help and encouragement at all stages of this investigation, and the surgeons of the Royal Aberdeen Hospital for Sick Children for permission to study patients under their care. We also thank the surgical registrars and residents who helped in obtaining many of the specimens, and Mrs. Helen Gallicker for technical assistance.

\section{REFERENCES}

Aird, I. (1945). Brit. med. J., 2, 680

Barr, J., Kjellén, L., and Svedmyr, A. (1958). Acta paediat. (Uppsula), 47, 365 .

Bell, J. A. (1957), Amer. J. Ophthal., 43 (4), pt. 2, p. 14.

Bell, T. M. (1962). Scot. med. J., 7, 85.

Turner, G., Macdonald, A., and Hamitton, D. A. (1960) Lancet, 2, 1327

Committee on the E.C.H.O. Viruses (1955). Science, 122, 1187.

Dascomb, H. E., and Hilleman, M. R. (1956). Amer. J. Med., 21, 161.

Elvin-Lewis, M., and Melnick, J. L. (1959). Proc. Soc. exp. Biol. (N.Y.), 102, 647.

Garner, P. S. (1961). Brit. med. J., 2, 495

- Wright, A. E., and Hale, J. H. '(1961). Ibid., 2, 424.

Kjellén, L. (1955). Arch. ges. Virusforch., 6, 45. Sterner, G., Svedmyr, A. (1957). Acta paediat. (Uppsala), 46, 164 .

Landsman, J. B., MacAnespie, H., Weetch, W. J., and Bell, E. J. (1960). Brit. med. J., 2, 464 .

Pereira, M. S. (1960). M.D. Thesis, Aberdeen University.

Ross, J. G., and Potter, C. W. (1961). Lancet, 1. 81.

Rowe, W. P., Huebner, R. J., Gilmore, L. K., Parrott, R. H and Ward, T. G. (1953)." Proc. Soc. exp. Biol. (N.Y.), 84, 570 . Sobel, G., Aronson, B., Aronson, S., and Walker, D. (1956).

Steyn, J., and Betl, T. M. (1961). Brit. J. Surg., 48, 466.

Van der Veen, J. (1958). Ann. Soc. belge Méd., trop., 38, 891. Williams, W. O. (1961). J. Coll. gen. Practit., 4, 181.

Two international bodies-the United Nations Scientific Cammittee on Effects of Atomic Radiation and the International Commission on Radiological Protection-have been especially established to collect and evaluate information on radiation effects and to make recommendations on permitted levels of exposure, but several other international organizations have a substantial interest in the relationship between ionizing radiation and health. Chief among these are the International Atomic Energy Agency and the World Health Organization, and in October, 1960, the two organizations jointly sponsored a scientific meeting on the diagnosis and treatment of acute radiation injury. The proceedings of this meeting, together with a number of other recent developments in radiation medicine, were reviewed in a special number of the W.H.O. Chronicle published in December, 1961, with the title Radiation and Health. The articles have now been reprinted in brochure form. and are available from H.M.S.O., P.O. Box 569, London S.E.1. (Price 1s. 9d.) 